\title{
The Development of Blended Learning Method in the Medical Surgical Nursing Courses IV in Pandemic Covid -19 at Faculty of Nursing Universitas Andalas
}

\author{
Leni Merdawati ${ }^{1,{ }^{*}}$ Boby Febri Krisdianto ${ }^{1}$, Mulyanti Roberto ${ }^{1}$, Fitri Mailani ${ }^{1}$, Devia Putri \\ Lenggogeni ${ }^{1}$, Rahmi Mutia ${ }^{1}$
}

\author{
${ }^{1}$ Faculty of Nursing, Universitas Andalas \\ *Corresponding author. Email: lenimerdawati@nrs.unand.ac.id
}

\begin{abstract}
The medical surgical nursing courses IV is one of the courses of expertise for nursing students in applying nursing care to adult patients who have disorders of the respiratory, cardiovascular, haematological, endocrine, immunology, digestion, urinary, musculoskeletal, integument, sensory perception, and neurological systems. Learning in this course should be in the form of clinical practice to the hospital, but due to the Covid-19 pandemic, students cannot do field practice so the development of a blended learning method is a solution to achieve the expected competencies. Blended learning is a learning effort with a combination of various online, offline and face-to-face learning modes (in-person learning) in the form of synchronous or asynchronous learning. The development of the learning model begins with developing the program and semester learning activities plan, development of students handbooks and textbooks of medical surgical nursing course, development of learning method materials, development of students assignment and development of evaluation methods. Forms of learning that can be applied in this course include virtual synchronous (virtual class and conference), self-paced asynchronous (reading material, watching lecture videos, case studies, and simulation), collaborative asynchronous by discussion forums and small group discussions. Blended learning is expected to be able to improve learning outcomes and competencies in the medical and surgical nursing courses IV. Further research is needed to evaluate blended learning applications on the achievement of learning objectives and competency in the medical surgical nursing courses IV with blended learning.
\end{abstract}

Keywords: Blended learning, medical surgical nursing courses IV, Covid-19

\section{INTRODUCTION}

The medical surgical nursing courses IV is an application course in the clinical practice setting in achieving clinical competence in the medical surgical nursing courses IV. This course is a group of expertise courses through the application of theory and nursing process that have been studied in medical surgical nursing courses I, II and II. The focus of this courses is on meeting the nursing process of adult patients with multiple system disorder such as respiratory, cardiovascular, haematological, endocrine, immunology, digestion, urinary, musculoskeletal, integument, sensory perception, and neurology system. The application of nursing care in the clinical practice of medical surgical nursing emphasizes the ability to build students' professionalism, reflective learning and the ability to provide nursing care. Providing nursing care includes fostering a therapeutic relationship with the patient, conducting nursing assessments, formulating nursing diagnoses that are appropriate to the case, planning nursing actions ranging from simple to complex, and conducting evaluations in accordance with the action plan. The learning process in the previous year was through clinical practice at the hospital, case study, case presentation, and collaborative learning, but in the current
Covid-19 pandemic situation, the learning method uses the blended learning.

Blended learning is an innovative concept that embraces the advantages of both traditional teaching inthe classroom and information and communications technology (ICT) to support, enhance, and optimise the delivery information. Blended learning including both offline learning and online learning. It has scope for collaborative learning; constructive learning and computer assisted learning (CAI). Blended learning needs rigorous efforts, right attitude, handsome budget and highly motivated teachers and students for its successful implementation. As it incorporates diverse modes so it is complex and organizing it is a difficult task. Worldwide research has shown that ICT can lead to an improved student learning and better teaching methods.

\section{METHODS}

\subsection{Development of program and semester activities} learning plan

The initial development stage is to analize and develop a program and semester activities plan. The learning of the medical and surgical nursing courses IV before the Covid- 
19 pandemic was carried out completely with live synchronization in the the clinical practice field in the hospital. Students practice in the hospital, do the patient assessments and formulate nursing process. Students are mentored by academic and clinical supervisors. Due to the covid-19 pandemic conditions, blended learning is the right solution and facilitates the achievement of learning competencies. Learning methods are carried out in the form of virtual synchronous, self-paced asynchronous and collaorative asynchronous. (C. Uwes Anis, 2017)

\subsection{Development of Students handbook and Textbook of the medical surgical nursing courses IV}

The next stage of development is to make a guidebook for the implementation of medical surgical nursing courses IV learning in the form of a manual for students and lecturers. To make it easier for students in the learning process, the teaching team also formulated a medical surgical nursing courses IV textbook which contains all the materials, scenarios and examples of scenario completion in the nursing care application.

\subsection{Development of learning methods material}

Learning methods in the form of synchronous and asynchronous learning. Synchronous form of learning through MS - Team, Skype, Zoom meeting, asynchronous learning in the form of independent learning, students conduct direct assessments on adults who experience in the various system disorders in the family or community where the student lives. Students make simulation videos and educational videos on managed patients. The development of learning methods begins with the development of the ilearning website. The course coordinator discusses and prepares of program and semester activities plan, guide books with the teaching team, prepares learning videos starting from explanation course videos, introductory lectures and learning videos according to meetings and topics. Videos are uploaded into i-learning so that students can access all material, guidebooks and learning videos.

\subsection{Development of students assignment}

The assignment of students in this study is very different from learning in the previous year. Students are given a target to be able to formulate nursing process in a given case, make videos of nursing ang health assessments and decide nursing diagnosis and nursing interventions. Students gain clinical experience through managing adult patients with various system disorders who are family members or in the community in the student's neighbourhood.

\subsection{Development of evaluation methods}

The evaluation method in the IV medical surgical nursing course is to assess the learning process, such as case reports for each system disorder (35\%), simulation videos (20\%), comprehensive case reports (15\%), midterm exams $(15 \%)$, and final exams $(15 \%)$.

\section{RESULTS AND DISCUSSION}

We can see the develop of blended learning in the medical surgical nursing course IV result in the table below:

Table.1 Step of Development Blended Learning in the Medical Surgical Nursing Courses IV

\begin{tabular}{|l|l|}
\hline No & \multicolumn{1}{|c|}{ Steps of Development } \\
\hline 1. & $\begin{array}{l}\text { Formulate the program and semester learning } \\
\text { activities plan }\end{array}$ \\
\hline 2. & Making a lecture rideos \\
\hline 3. & Formulate students and lecturer handbook \\
\hline 4. & Update i-learning website \\
\hline 5. & Arrange the textbook draft \\
\hline
\end{tabular}

Table. 2 . The Application Blended Learning Seting in Medical Surgical Nursing Courses IV

\begin{tabular}{|l|l|l|}
\hline \multicolumn{3}{|c|}{ The Application Blended Learning Seting Methods } \\
\hline Virtual & Self-Paced & Collaborative \\
sxnchronuos & Asynchronous & Asynchronous \\
\hline -Virtual class & -Reading material & -Forum \\
-Conference & -Wacthing lecture & discussion \\
& video & (I-learning) \\
& -Case study & -Small group \\
& -Simulation /practice & disscussion \\
\hline
\end{tabular}

Blended learning is a form of "integrated learning", "hybrid learning", "multi-method learning. However," mixed learning "is used with increasing frequency in academic settings, and is becoming an effective learning solution during the Covid-19 pandemic. is a learning method that combines e-learning with other forms of flexible learning and more traditional forms of learning. Blended learning combines e-learning learning, in its various forms, combined with traditional forms of learning such as "classroom" learning. (Stockley, 2005). (2004) in

S. Mehmed, 2016 describe the evolution of learning from the traditional 1950s classroom through the current mixed learning environment.The final stage is Blended Learning: 2000 -, which includes Web (S. Mehmet, 2016).

Blended learning in this sense is the latest online innovation as a result of integrating technology into education. Technological advances and changes in teaching and learning approaches (from teacher-centered to studentcentered) are facilitating new models such as mixed-out learning. Watson (2008) suggests that mixed learning involves a shift in strategy in three areas: from teachercentered learning to student-centered learning, from limited to high-frequency interactions between students and resources, and from intermittent to deliberate integration of formative assessment. and summative. In fact, educators have been preoccupied with integrating technology into the 
classroom for decades (Dziuban, Hartman, Moskal, 2004). The rapid changes in technology in our century have caused students and in general individuals and specialized students to change as well. Technology and students change rapidly and individuals have the capacity for this change, which implies that educators must embrace "the new digital reality of the computerized online world" (Jukes, 2008: 6). Buckley et al. (2002) and Tagg (1995) note a paradigm shift in higher education leading to new teaching and learning models.

Blended learning is learning that is supported by an effective combination of ways of delivery, different ways of teaching and learning styles and is found in open communication between all parts involved in training ". As for the advantages of using blended learning as a combination of direct (face-to-face) teaching and online teaching, it is more than that as an element of social interaction, namely:

a. There is an interaction between teachers and students

b. Teaching can also be online or face to face

c. Blended Learning $=$ combining instructional modalities (or delivery media),

d. Blended Learning $=$ combining instructional methods

The benefit of using e-learning and blended learning in education today is that e-learning provides flexibility in choosing the time and place to access lessons. students do not need to travel to where the lessons are delivered, elearning can be done from anywhere, whether they have access to the Internet or not.

E-learning provides an opportunity for students to independently take control of learning success. Learners are free to decide when to start, when to finish, and which parts of the module they want to study first. If, after repeating, there are still things that they do not understand, the learner can contact the instructor, the resource person via email, chat or participate in interactive dialogue at certain times. You can also read the results of the discussion on the message board available on the LMS (Learning Management System).

Blended learning is learning that combines or combines various web-based technologies to achieve educational goals. In this course, the I-learning, MS-Team, Skype, Zoom meeting and google classroom applications have been used. Blended learning is a combination of various learning approaches (such as behaviorism, constructivism, cognitivism) to produce an optimal learning achievement with or without learning technology. Students learn independently by studying the given scenarios, looking for sources / references, and making simulation videos of health assessments in patients. This learning also combines assignment methods and learning technology (Driscoll, 2002).

\section{CONCLUSION}

The development of blended learning methods on the medical surgical nursing courses IV provide results or ouput in form the blended learning program and semester learning activities plan, lecture videos, students and lecturer handbook, updating i-leraning website and draft of the textbooks. Further research is needed to evaluate blended learning applications on the achievement of learning objectives and competency in subjects with blended learning.

\section{ACKNOWLEDGMENT}

This work was supported by Lembaga Pengembangan Pendidikan dan Penjaminan Mutu (LP3M) Universitas Andalas.

\section{REFERENCES}

[1] C. Uwes Anis, PEDATI; Model Desain Sistem Pembelajaran Blended ; Panduan Merancang Mata Kuliah Daring SPADA Indonesia, Direktorat Jenderal Pembelajaran dan Kemahasiswaan Kementerian Riset, Teknologi, dan Pendidikan Tinggi, 2017. https://mooc.unud.ac.id/

[2] Driscoll, M. Blended Learning: Let's Get beyond the Hype. IBM Global Services, 2002.

[3] H. Yane, Model Pembelajaran Blended Learning dengan Media Blog.

https://sibatik.kemdikbud.go.id/inovatif/assets/file_uploa d/ pengantar/pdf/pengantar_3.pdf

\section{Conference paper}

[1] S. Mehmet, Blended Learning Environment in Vocational Education, The $5^{\text {th }}$ International Conference on Virtual Learning ICVL 2010. https://www.researchgate.net/publication/298788637. 2016 